\title{
The "Inversions" of Intentionality in Levinas and the Later Heidegger
}

\author{
AdAm KonOPKA
}

This essay contests the Levinasian characterization of Heideggerian ontology in light of Heidegger's later work. Levinas did not seriously engage the later portion of the Heideggerian corpus in which an important shift occurred in the questioning of being, largely releasing it from Levinas's critique that it is circumscribed within a horizon of Dasein's active disclosure of Seinsverständnis (understanding of being). In what follows, I will situate Levinas's own reversal of intentionality in Heidegger's later thought, where intentionality also undergoes a radical transformation and concepts such as the ontological horizon are traversed. My claim is that in both cases there is an attempt to discover a ground that is not proper to the structure of Husserlian intentionality, which is to say, a ground that is prior to the constitutive comprehension of intentional analysis or Dasein's active disclosure of the being of beings. More specifically, I will argue that there is a possibility of reading Heidegger's eventual articulation of Ereignis, the event of appropriation, as the ground found on the other side of manifestation, that is, proper to being itself rather than Dasein. This notion of event, perhaps most clearly articulated in the analysis of the es gibt in Time and Being, is never fully manifested, and therefore never fully pertains to the ontological horizon of Verständnis (understanding).

While Levinas's corpus is deeply indebted to Husserl's theory of intentionality, its ultimate significance stems from the contestation of the ethical implications of its 
epistemological account of intersubjectivity. Levinas understands Husserlian intentionality as privileging a representational model of consciousness, which is to say, every objectifying act is necessarily either a representation or founded on a representation (Totality and Infinity 122). The moment of representation inherent in intentionality, according to Levinas, arises from the affirmation that "the object of consciousness, while distinct from consciousness, is as it were a product of consciousness, being a 'meaning' endowed by consciousness, the result of Sinngebung [meaning-bestowal]" (123). This reduction of the represented object to a product of meaning-bestowing subjectivity and to something ontologically distinct from the fully transcendent object is the basis on which Levinas characterizes representation as "the defining of the other without being determined by the other" (125). ${ }^{1}$

Levinas's interpretation of Husserlian intentionality as representational has its origin in an earlier assessment of the primacy of cognitive presentations in Husserl's phenomenology. While Husserl systematically investigated various modalities of objectifying acts-i.e., perceptual, practical, axiological, and volitional acts-it is the constitution of the cognitive content of theoretical objects that serve as the paradigm of intentionality. Even given Husserl's emphasis on lived experience (Erlebnis) in Ideas $I$ and $I I$, he nevertheless continues to maintain that practical, axiological, and volitional acts are necessarily founded on the doxic characteristics of objectifying acts that have cognitive content; in this way, he relegates even non-theoretical experience to a model akin to cognitive presentations. ${ }^{2}$ This sustained preference for and elevation of the theoretical mode of intentionality, according to Levinas, not only leads to an ahistorical conception of being but reveals the desire for sovereignty as the inner motivation of Husserlian phenomenology. According to Levinas, this privileging is never justified and on the last page of his most extended work on the issue he states, "Husserl posits the freedom of theory 
just as he posits theory" (Theory of Intuition 222). Levinas's critique of intentionality as representational thus originates in the critique of intentionality as an unjustified prioritization of theoretical cognition that ultimately leads to an intellectualism or gnosticism.

The Heideggerian inflection of this criticism is well known. From the beginning, Levinas not only treats the problems of constitution and representation as ontological problems, but he accepts Heidegger's view of Dasein's historicity and affectivity over and against the supposed Husserlian intellectualism. ${ }^{3}$ Consciousness and the clarity of evident meaning always already take place in the more primordial drama of our "concernful dealings" in a concrete existence and history. For Heidegger and Levinas, these concernful dealings cannot be adequately understood by theoretical evidence, nor can the clarity of objectification be the authentic mode of comprehension.

The import of Levinas's critique of Husserl, seen as a repetition and radicalization of the Heideggarian evaluation of the representation and intellectualism of Husserlian phenomenology, becomes all the more significant when it is eventually redoubled against Heidegger himself. Although Heidegger opposed the identification of philosophy with objectifying theory he nevertheless remained, according to Levinas, within the logocentrism of the Western tradition when he maintained that the fundamental existential is a form of comprehension. While Heidegger demonstrated that being grounds the very intentions that give rise to the comprehension of beings, this structure of Seinsverständnis nevertheless functions as the disclosure of Dasein's possibilities through the assimilation and possession of the objects of its own practical and affective concern (Levinas, Discovering Existence 118).

Levinas's first serious attempt to depart from the climate of this Heideggerian thought occurs in his 1951 essay "Is Ontology Fundamental?"-perhaps the decisive text for his 
subsequent development. ${ }^{4}$ In this essay, he argues that even though Heideggerian ontology was able to exceed the intellectualism charged to Husserl, it was unable to describe the intersubjective relation because in any given situation a particular being is always already understood within the horizon of being as such. This ontological horizon forms the ultimate ground for the manifestation of any particular being and is ultimately circumscribed by the Platonic legacy which makes claims to comprehension through a reference to a universal eidos. "Understanding is the very event that existence articulates. All incomprehension is only a deficient mode of comprehension. It turns out that the analysis of existence and of what is called its haecceity $(D a)$ is only the description of the essence of truth, of the condition of the very understanding of being" (Levinas, "Is Ontology Fundamental?" 5).

So much is well-known, but I shall argue that the development in the later Heidegger falls outside the scope of Levinas's methodological critique, and in so doing I depart from the orbit of scholarship which has previously centered the Levinasian problematization of Heideggerian ontology within the confines of Heidegger's earlier work (especially Being and Time). ${ }^{5}$ Rather than investigating the validity of Levinas's critique of Heidegger on the basis of Heidegger's early work, my analysis brings Levinas's critique to bear on Heidegger's later work and argues that Heidegger himself successfully performs an "inversion" of intentionality through the discovery of the withdrawal of Ereignis. Both Levinas and the later Heidegger, in short, attempt a traversal of the horizon of Husserlian intentionality. In drawing this methodological association, I do not wish to conflate the uniqueness of their respective projects. Heidegger and Levinas negotiated the boundaries of intentional life at different edges, so to speak, and with radically different implications. Examining the similarities between the two departures, however, can enrich the contemporary discussion of the borders and limitations of the phenomenological 
enterprise and illuminate the pitfalls involved in venturing beyond a describable experience of the given.

\section{The Levinasian "Inversion" of Intentionality}

Before turning to the later Heidegger's discovery and articulation of Ereignis, it is instructive to briefly rehearse Levinas's well known presentation of what in Totality and Infinity he called an "intentionality of a wholly different type" (23) and in Otherwise Than Being a "radical reversal, from cognition to solidarity" (119). Perhaps this presentation is more appropriately described as pre-intentional and pre-ontological due to the priority inspired by the ethical relation as the transcendental ground of subjectivity. The Levinasian problematization of intentionality, moreover, was never meant to render intentional analysis null and void, but to search for a prior relation of transcendence not proper to acts of objectification.

As is well known, Levinas attempted to locate this pre-original or anachronic past in a paradoxical discourse that precedes, but cannot properly enter into, any known discourse. In talking or writing I always address myself to another person who I assume hears me. This process of saying is one that necessarily includes a relation between speaker and hearer (and vice versa). However, the Other to whom I speak is not before me as a phenomenon that I treat as a reflective theme in the manner characteristic of the theoretical approach to phenomena. To do so would be to neutralize the encounter with the Other to whom I am passively appropriated prior to any reflective stance that lends itself to objectification.

For Levinas, the proximity of this face-to-face encounter of the saying is an orientation that resists the possibility of being reduced to cognition within an intentional or ontological horizon. To do so would be to convert the saying into the said. To take this "detour of ideality" is 
to take the sensibility of another's face as just another event along this horizon. Levinas, on the other hand, started with sensibility interpreted not as a knowing, but as a proximity that is the transcendental condition of this knowing. "Proximity ... is the relationship with what is not disproportionate to the arché in thematization, but incommensurable with it" (Otherwise Than Being 100). While this relationship of proximity is incommensurable with consciousness, it does become a trace by which subjectivity is appropriated to responsibility. Prior to any Sinngebung or meaning-bestowal (Totality and Infinity 51) located on an intentional or ontological axis, this substitution has an anteriority that is "older" than the a priori (Otherwise Than Being 101). Thus consciousness is enigmatically affected and endowed with responsibility before it has a chance to pose its questions and apply its concepts.

It was important for Levinas that this asymmetrical responsibility be described prephenomenally and pre-ontologically, and he went to great lengths to analyze it through his wellknown discussions of substitution, obsession, accusation, election, and persecution. Throughout these discussions, all knowledge is conceived as the constitution of objects through the reduction of the other to the same. Formulated in Heideggerian terms, comprehension is attained when any particular being (including an intersubjective one) is seen in its relation to the horizon of being. Levinas understands this Heideggerian model of understanding as already having said too much; rather than offering an invocation irreducible to thematization, it fails to grasp transcendence as it is in itself. The Other has a meaning prior to and independent of all constituted meaning (including the meaning of being) and hence is the exemplary case of meaning that not only short circuits and undercuts conatus essendi (life struggle), but also establishes an ethical responsibility as the ground of one's being. 


\section{Heidegger: The Hiddenness of Ereignis}

Levinas's development of the ethical relation is formulated through a sustained polemic against Heidegger. As noted above, it is Heidegger's own critique of Husserlian intentionality which Levinas eventually applies in a modified form to Heidegger himself. In so doing, however, he relegates his appraisal of the ontological horizon to Being and Time (and surrounding texts) where the phenomenological hermeneutic of Dasein has a distinct heritage in Husserlian intentionality. ${ }^{6}$ The early Heidegger grounded intentionality in the practical comportment of Being-in-the-world through the circumspection (Umsicht) of Dasein's everyday dealings (Umgang) in order to reveal the basic structure of Dasein as care. Care, in turn, is made possible by an ecstatic temporality that constitutes the fundamental "outside itself," a selftranscending that opens the horizons of past and future. By the end of Being and Time, the reader is left with the claim that temporality is the basic structure of Dasein and perhaps the very horizon of being itself.

If this were the extent of Heidegger's development of the theory of intentionality, it would seem as though Levinas's objections might have a foothold. However, the transformation from Heidegger's earlier phenomenology to the thinking of being characteristic of the later Heidegger problematizes Levinas's objections. This transformation of focus-a reversal in manner and method brought about through the (in)famous Kehre (tack or turn)—represents a shift from the earlier questioning of Dasein's being and its disclosure of being to the notion of Ereignis as the event that passively appropriates the very ontological dimension of Dasein. ${ }^{7}$

Perhaps nowhere is this transformation of the question of being more typified than in the articulation of the es gibt (it gives) in the lecture, On Time and Being, where Heidegger attempts to articulate the fundamental ontological event "without regard to its being grounded in terms of 
beings" (2). From the beginning of this text, the reader is reminded that, according to the ontological difference, neither being nor time can be understood as $a$ thing. Furthermore, being and time have a reciprocal relationship, but one in which "neither can ... Being be addressed as something temporal nor ... time be addressed as a being" (3). And yet there is a relation between the two "which holds both issues toward each other and endures their relation" (4). In order to access this relation, which is the task of thinking, it is necessary to avoid claiming "being is" or "time is." Rather, it is more appropriate to say "It gives being" and "It gives time" (5). This configuration of the passive appropriation of being and time as a gift, however, only seems to displace the opacity already present between being and time onto the "it" of the "it gives" (es gibt). Heidegger claims that the "it" has been unthought in the Western tradition in favor of being (which, in turn, has been conceptualized with regard to beings).

It is possible, according to Heidegger, to approach the "it" of the "it gives" as that which gathers the sending of being as presence and the extending and bringing near of the dimensions of time. The "it" refers to a "giving which gives only its gift, but in the giving holds itself back and withdraws" (8). In the sending of being, this giving remains concealed by holding itself back, going unnoticed and unmanifested in its absence. In the extension of time, it keeps the dimensions of time open to each other by denying and withholding its own advent in the present.

It is not enough to hold these two givings (sending and extending) side by side. They can be associated or "gathered together" in what Heidegger calls Ereignis-the event of appropriation. Heidegger eventually articulates the "it" of the es gibt as Ereignis. This event of appropriation does not designate a kind of horizon akin to the ontological horizon of the early Heidegger. Nor does it refer to the manifestation of being through Dasein's disclosure of its own possibilities. Rather, Ereignis designates a groundon the other side of the appearance and its 
horizon, a ground that cannot be properly attributed to Dasein because it itself remains concealed in the process of manifestation. The discovery of this ground is philosophically significant, according to Heidegger, because it departs from the misguided valorization of presence in the metaphysical tradition that still encumbers Husserlian intentionality.

This articulation of sheer occurrence without reference to the thing occurring does not register in the appearance because it passes by unnoticed, unthought, and unthematized (in the Levinasian and Heideggerian sense of the word) in favor of what is given. Heidegger describes this radical absence as a withdrawal:

Along the way, we have already thought more about it, although it was not explicitly said: namely, that to giving as sending there belongs [a] keeping back-such that the denial of the present and the withholding of the present ... shows something like a selfwithdrawing, something we might call for short: withdrawal. But inasmuch as the modes of giving that are determined by withdrawal-sending and extending-lie in Appropriation, withdrawal must belong to what is peculiar to the Appropriation" (On Time and Being 22; my emphasis).

In giving through the sending of being and the extending of time, there is a withholding. The event as such does not appear, but refuses its unconcealment, and goes unnoticed and unthematized in favour of the presencing of being and the openness of time.

The whole orientation of the determination of being in terms of Ereignis can be interpreted as a return to a more originary origin, an a priori ground that, rather than carrying out the constitutive work of the disclosure of possibilities, instead locates Ereignis as the ground of the subjectivity of the subjective.

Nowhere is this orientation more evident than in Contributions to Philosophy: (From Enowning) in which Heidegger attempts to think from the site of Ereignis. Thinking from the site of Ereignis occupies neither a "point of view" nor a kind of lived experience akin to an intentional act. Rather, Heidegger's articulation of Ereignis attempts to think from this position 
as opposed to thinking about it, trying to actually perform the appropriation of Dasein as the eventual site of openness rather than remaining within a presentational perspective.

Attempting to think from the site of Ereignis, Heidegger elaborates on withdrawal as the peculiar characteristic of Ereignis. In order to "say being" in an originary manner rather than making prepositional statements which lose the eventful character of the giving of being, Heidegger proposes various guiding attunements (i.e., startled dismay, reservedness, and awe) which prepare thinking for an increasing awareness of the intrinsic withdrawal of Ereignis. The silencing of metaphysical language only occurs when the confrontation with the radical abyss (Ab-grund) of the self-withdrawal of Ereignis makes it possible for Dasein to be open to the generosity of the sending of being and the extending of time.

\section{The Similarities of Levinas and the Later Heidegger}

Several relevant methodological parallels can be drawn between Levinas and the later Heidegger. First, both projects share a challenge to the primacy of a theoretical mode of apprehension characteristic of Husserlian intentionality. The search for a pre-original meaning (Levinas) and a more originary origin (Heidegger) oppose axiological and affective (Levinas) and practical and affective (Heidegger) modes of experience to the mono-directional founding relation of cognitive presentation. Thus, the initial "inversion" of Husserlian intentionality is taken to have occurred through the reversal of the founding relation, which is to say, cognitive presentation is founded upon and derived from practical, affective and axiological modes of experience.

Second and more significantly, the priority of non-theoretical modes of experience implies a radicalization of the constitutive ground of the universal and necessary features of 
experience characteristic of the Husserlian notion of the transcendental. On the one hand, Levinas's attempt to prioritize the irreducible proximity of the ethical relation implies a location of the ground of transcendental subjectivity in the encounter with the Other. The saying grounds the said such that the said presupposes and forms a unity with the saying. As such, the irreducible intersubjective encounter implicit in discourse is the transcendental condition for subjective meaning because all meaning is rooted in communication. On the other hand, the later Heidegger's attempt to articulate Ereignis as the event that appropriates the subjectivity of the subjective can be seen as pointing to a ground on the other side of manifestation, not proper to Dasein, but proper to itself. While Ereignis is a necessary and universal condition of the manifestation of being (and, in turn, beings), it is not reducible to this manifestation. As we have seen, this radicalization of the ground of experience is made possible through the withdrawal of Ereignis.

Third, both Heidegger and Levinas take recourse to a radical notion of absence in order to traverse the presentational model of intentionality. Perhaps their respective articulations of absence can best be framed by the Hegelian injunction to tarry with the negative. On the one hand, Levinas locates the absolute nothingness of Hegel's logic in the intersubjective relation, where the face of the Other takes the form of the command, "Thou shalt not kill (annihilate)" that includes the double negation: 1) thou shalt not, 2) annihilate. As we have seen, the doubling of negation in this formula is Levinas's initial attempt to articulate the abyss (Abgrund) of the Other. On the other hand, Heidegger locates radical nothingness in the withdrawal of Ereignis, the intrinsic self-absence that appropriates Dasein into the openness of experience. The givenness of the given for Dasein includes a sense of gratitude such that "All thinking is thanking." 
While these three parallels can reveal the methodological similarities between the projects of Levinas and the later Heidegger, I do not want to imply that the two can be conflated. The respective radicalizations of Husserlian phenomenology take place in dramatically different contexts with dramatically different concerns and implications. The purpose of their association is to defend the development which occurs in the later Heidegger from the Levinasian critique of the ontological horizon. My intention has been to show that Heidegger's articulation of the withdrawal of Ereignis largely releases him from the charge that the fundamental existential is a form of comprehension. Ereignis is not subject to the comprehension of the ontological horizon because its withdrawal does not allow it to be thematized. As it is withheld from manifestation, Ereignis slips by unnoticed in favor of the sending of being and the extending of time. As such, it does not occur in a way proper to Seinsverständnis.

\section{Conclusion}

The association of the Heideggerian and Levinasian "inversions" of intentionality points to three implications for the practice of phenomenology. Both Levinas and the later Heidegger come up against a parallel problematic regarding the inadequacy of philosophical language and the need for continual self-effacement in their descriptions. In the face-to-face encounter, the saying can only be an orientation that takes place within the ethical relation. However, by disclosing the proximity of the saying, Levinas inevitably must take a "detour of ideality," so to speak, and convert the saying into a said. Ultimately, in order to resist ontologizing the saying, Levinas must perform a continual unsaying of the said. Meanwhile in attempting to think the occurrence of Ereignis independent of anything actually occurring, Heidegger is forced to perform a poetic rendering of the limits of experience. In so doing, he runs the risk of a 
performative contradiction when he tries to shed light on that which refuses to be illuminated. To describe experience, let alone the limits of experience, is to bring it to presence in order that the unthematic can become thematic. Both Levinas and the later Heidegger force their language to thematize the unthematic as unthematic, but as a result, a performative tension constantly lurks in their respective ways of speaking and writing.

Second, both Levinas and the later Heidegger invert intentionality by exploring the passivity in which givenness occurs. Whereas intentional acts and Dasein's concernful disclosure can be described through their active constitution, the inversions of intentionality discussed above are explorations of radical passivity. While the face of the transcendent Other appropriates the ethical subject by addressing it with the injunction against murder, Ereignis is an event that appropriates Dasein such that the sending of being and the extending of time might be given. Both the ethical subject and Dasein undergo appropriation. Heidegger is arguably more radical in the exploration of passivity because he attempts to think not merely about Dasein's appropriation from Dasein's vantage point, but he attempts to think the withdrawal of Ereignis from the occurance of being and time. Heidegger's articulation of Ereignis, in other words, actually attempts to think from passivity itself and thereby performs the appropriation of Dasein. In the process, the first person perspective is displaced and the centrality of intuitive givenness for the phenomenology undergoes an innovation.

Third, the inversions of intentionality reveal the limitations of the horizon of phenomenological reflection by calling attention to the boundaries of experience. Phenomenology describes the intuitive givenness of experience, and both Levinas and the later Heidegger demonstrate that this intuitive givenness is incomplete in itself. A complete accounting for what is given in intuition ultimately requires a surpassing of intuition. The 
"inversions" of intentionality are radically motivated to surpass the boundaries of experience because they do not accept this incompleteness. In the process of probing the edges of the intentional horizon, they offer an articulation of those edges and illustrate how one might explore beyond them.

\section{Notes}

${ }^{1}$ It is on this basis that Levinas understands Husserl's idealism and his relation to Kant. The centrality of representation that Levinas gives to Husserlian intentionality is sustained throughout his commentaries. For instance, "The primordial role Husserl causes representation to play is not an accident or a philosopher's obstinacy, to be the despair of his disciples, but one of his most characteristic positions, without which his work would remain incomprehensible" (Discovering Existence 62). As Adriaan Peperzak claims, "In this sense Levinas characterizes Husserl's philosophy, in a Heideggarian vein, as a Vorstellende, 'objectifying' or 'representationist' mode of thought, a characterization maintained in later articles on Husserl" (41).

2 This relegation of non-theoretical intentions to the theoretical occurs through the founding relation of the latter to the former. To say that $A$ is founded on $B$ is to say 1) A necessarily presupposes $\mathrm{B}$, and 2) A necessarily forms a unity with $\mathrm{B}$. The founding/founded relation can be either reciprocal or one-sided. The classical example of a reciprocal founding relation is that between color and extension. For brief discussions on the Levinasian characterization of doxic theses, see Wyschogrod (48) and Peperzak (42).

${ }^{3}$ The textual evidence for the Heideggerian inflection is manifold. For instance: "Even though Husserl maintains the profound idea that, in the ontological order, the world of science is posterior to and depends on the vague and concrete world of perception, he may have been wrong in seeing the concrete world as a world of objects that are primarily perceived. Is our main attitude toward reality that of theoretical contemplation? Is not the world presented in its very being as a center of action, as a field of activity or of care - to speak the language of Martin Heidegger?" (Totality and Infinity 119). Peperzak goes as far to say that the critique in the 1940 article, "The Work of Edmund Husserl," is "wholly Heideggerian" (44).

${ }^{4}$ Peperzak comments on the central place which this text has in Levinas's development, "For the first time in one of his articles on Heidegger, Levinas answers this question [of the motivation of refusing the primacy of understanding and comprehension] with the clear statement that Heidegger's understanding of existence and of understanding does not permit another human being (autrui) to present him- or herself as he or she is. This thesis is the center and source of 
Levinas's development from the 1940s until the appearance of Totality and the Infinite in 1961" (51).

5 See, most notably, Manning. The current defense of the later Heidegger from the Levinasian critique is analogous to Ian Angus's defense of the later Husserl. See the seventh chapter, entitled "Beyond Gnoseology," of Angus, (Dis)figurations.

6 There are clear differences between Heidegger's articulation of Being-in-the-world and Husserl's account of the structure of intentionality. According to Heidegger, it is because Husserl took cognitive intending to be the primary mode of his analysis of intentionality that he neglected to appreciate the way in which Dasein primordially transcends itself as Being-in-theworld. While this transcendence can appropriately be described as an ontological ecstatic temporality, the latter temporality is different from the ontic temporal structures of intentionality. Because intentionality gives an account of the relation between objects and states of affairs in the context of ordinary time, Husserl's eventual development of a more primordial dimension of time-consciousness remained confined to the "internal" immanence of the subject, exposing the psychological assumption inherent in the theory of intentionality. Thus, in Heidegger's introduction to Husserl's lectures on internal time-consciousness he claims, "Even today, this term 'intentionality' is no all-explanatory word but one which designates a central problem" (Internal Time-Consciousness 15). In contrast to this Heideggerian account of the relation between Being-in-the-world and the structure of intentionality, relatively recent scholarship has emphasized their intimacy. See, for example, Hopkins and Crowell. For the purposes of this essay, I will accept the association of the early Heidegger with Husserl's theory of intentionality.

${ }^{7}$ See Richardson xxvi and Sheehan 3.

\section{Works Cited}

Angus, Ian. (Dis)figurations: Discourse/Critique/Ethics. London: Verso, 2000.

Crowell, Steven Galt. Husserl, Heidegger, and the Space of Meaning: Paths Toward Transcendental Phenomenology. Evanston: Northwestern University Press, 2001.

Drummond, John. "The Structure of Intentionality." The New Husserl: A Critical Reader. Ed. Donn Welton. Bloomington: Indiana University Press, 2003. 65-92.

Hopkins, Burt. Intentionality in Husserl and Heidegger: The Problem of Original Method and the Phenomenon of Phenomenology. Dordrecht: Kluwer Academic Publishing, 1993. 
Heidegger, Martin. Being and Time. Trans. John Macquarrie and Edward Robinson. New York: Harper Collins, 1962.

—. On Time and Being. Trans. Joan Stambaugh. Chicago: University of Chicago Press, 1972.

- Contributions to Philosophy: (From Enowning). Trans. Parvis Emad and Kenneth Maly. Bloomington: Indiana University Press, 1999.

Husserl, Edmund. Cartesian Meditations: An Introduction to Phenomenology. Trans. Dorion Cairns. The Hague: Martinus Nijhoff, 1960.

-. Ideas Pertaining to a Pure Phenomenology and to a Phenomenological Philosophy. First Book. General Introduction to a Pure Phenomenology. Trans. Fred Kersten. The Hague: Martinus Nijhoff, 1982.

—. The Phenomenology of Internal Time-Consciousness. Ed. Martin Heidegger. Trans. James S. Churchill. Bloomington: Indiana University Press, 1964.

Levinas, Emmanuel. Totality and Infinity: An Essay on Exteriority. Trans. Alphonso Lingis. Pittsburgh: Duquesne University Press, 1969.

-. Discovering Existence with Husserl. Trans. and Eds. Richard A. Cohen and Michael B. Smith. Evanston: Northwestern University Press, 1998.

- Theory of Intuition in Husserl's Phenomenology. Trans. Adrian Orianne. Evanston: Northwestern University Press, 1970.

—. "Is Ontology Fundamental?" Emmanuel Levinas: Basic Philosophical Writings. Eds. Adriaan T. Peperzak, Simon Critchley, and Robert Bernasconi. Bloomington: Indiana University Press, 1996. 1-10.

—. Otherwise Than Being: Or Beyond Essence. Trans. Alphonso Lingis. Pittsburgh: Duquesne University Press, 1981.

Manning, Robert John Sheffler. Interpreting Otherwise Than Heidegger: Emmanuel Levinas's Ethics as First Philosophy. Pittsburgh: Duquesne University Press, 1993.

Peperzak, Adriaan. Beyond: The Philosophy of Emmanuel Levinas. Evanston: Northwestern University Press, 1997.

Richardson, William. Heidegger: Through Phenomenology to Thought. The Hague: Martinus Nijhoff, 1963. 
Sheehan, Tom. "Kehre and Ereignis: A Prolegomenon to Introduction to Metaphysics." $A$ Companion to Heidegger's Introduction of Metaphysics. Eds. Richard Polt and Gregory Fried. New Haven: Yale University Press, 2000. 1-26.

Wyschogrod, Edith. Emmanuel Levinas: The Problem of Ethical Metaphysics. New York: Fordham University Press, 2000. 